\title{
THE WINDING ROAD ON THE MEDIA LANDSCAPE
}

\section{THE ESTABLISHMENT OF ESTONIAN (TELEVISION) BROADCASTING BETWEEN 1992 AND 2016}

Andres Jõesaar

Tallinn University

Narva mnt 25

10120 Tallin

Estonia

andres.joesaar@tlu.ee

\begin{abstract}
This article explores how Estonian broadcasting (with a focus on television) tackled the challenges of transforming from a monopolistic party propaganda machine into a modern dual media system in which public service broadcasting and newly created private enterprises coexist, and how this process evolved in a small, post-Communist country. This article argues that the Estonian government's 'idealisation' of market forces supported by the European Union media policy, which is driven by common market ideology, did not account for the market's limitations and media companies' actual capabilities to provide a large range of media services.

The research methodology is based on an analysis of Estonian media legislation and the broadcasters' annual reports from the period 1992-2016. The article analyses the key connections between the financial conditions of the broadcasting industry and the adaptations made in broadcasting legislation in Estonia during the last 25 years.
\end{abstract}

Keywords: media policy, private broadcasting, public service broadcasting, Estonian Public Broadcasting, Estonia

\section{Introduction}

Starting in the late 1980s, the Eastern and Central European countries pursued the noble aim of changing from Communist-ruled countries to free and democratic welfare states. Having rejected the Communist regimes, a liberal free market strategy was introduced in most of the Central and Eastern European countries, particularly in the Baltic states. In their comparative study, Knell and Srholec ${ }^{1}$ show that, compared to other Central and Eastern European countries, Estonia took the most liberal way of development. The latter was chosen for rebuilding the state as a whole,

1 Mark Knell and Martin Srholec, 'Diverging pathways in central and eastern Europe' in: David Lane and Martin Myant, eds., Varieties of capitalism in post-communist countries, Palgrave MacMillan, 2007, 40-62. 
as well as designing the new media landscape. According to Blum, ${ }^{2}$ the media systems in Latvia and Lithuania are described as clientele-oriented while the Estonian media system is a public service. Still, all three Baltic media systems have strong roots in liberal media policy. ${ }^{3,4}$

In the majority of transition states, including the Baltics, commercial broadcasters were founded during the transmission period in the 1990s, most of the state-owned print media were privatised and state radio and television companies were transformed into public service broadcasters. For these transformations, institutional and professional guidance from Western Europe was widely used. ${ }^{5}$ Critics of these processes argue that the attempts to embed Western European media models into post-Communist countries lacked the common understanding of both sides. Firstly, the West didn't fully recognise the local circumstances. Secondly, the politicians in the transformation states did not comprehend the Western model, or at least, they lacked the knowledge (or will) of how to adapt it to the local environment. As a result, the embedded media regulation models didn't achieve the same results that they had in Western Europe. ${ }^{6}$ 'Europeanisation', as defined by Jakubowicz, ${ }^{7}$ had taken place.

Freedman ${ }^{8}$ argues that in media policy, everything is about politicians and market players and their power struggle to set the agenda according to their own self-interests. For the politicians in democratic states, the agenda should focus should on staying in power in order to serve society; for the market stakeholders the main interest is securing the sustainability and profitability of their businesses. The latter is supported by the theory of the firm, which asserts that 'the development and operation of firms is guided by the primary goal of maximizing profit and the value of the firm' ${ }^{9}$ If the media policy is biased by commercial players, the balance of the market could be hindered. While Hallin and Mancini ${ }^{10}$ admitted to difficulties in figuring out whether commercialization has increased or decreased the flow of political information, Aalberg ${ }^{11}$ and his colleagues found in their comprehensive research that the 'supply of political information varies according to the media system, or rather the degree of commercialization'. It is lowest in the most commercialized countries. This finding aligns with Curran's statement that 'a market-based media system is incapable of presenting a full range of political and economic interests in the public domain and finding expression in popular fiction': 12

Market forces do not guarantee that the media will serve their non-economic function as institutions of the democratic public sphere, and in many ways the breakdown of the forces that counterbalanced market forces has already taken its toll on the quality of news, sensationalism and other ethical problems, biases in the segments of society served by the media, and in some cases potentially dangerous concentrations of media power. ${ }^{13}$

2 Roger Blum, Lautsprecher und Widersprecher: Ein Ansatz zum Vergleich der Mediensysteme, Halem, 2014.

3 Anda Rožukalne, Latvia's Media Owners. A monograph on Latvia's media system and the most important owners thereof, Zinatne, 2013.

4 Deimantas Jastramskis, 'Reduction of liberalism in Lithuanian media policy', Central European Journal of Communication, Vol. 9, no 2 (17), Fall 2016, 164-179.

5 Marju Lauristin and Vihalemm, Peeter, 'The Transformation of Estonian Media and Society: 1987-2001' in: Peeter Vihalemm, ed., Baltic Media in Transition, Tartu University Press, 2002, 17-63.

6 Alison Harcourt, 'The Regulation of Media Markets in EU First-Wave Accession States in Central and Eastern Europe', European Law Journal 9, 3, 2003, 316-340.

7 Karol Jakubowicz,'The highways and byways of 'Europeanzation' in the media', Central European Journal of Communication 2, 1, 2009, 5-11.

8 Den Freedman, Politics of Media Policy, Polity Press, 2008.

9 Colin Hoskins, Stuart McFadyen, and Adam Finn, Media economics: applying economic to new and traditional media, Sage, 2004 , p. 3.

10 Daniel C. Hallin and Paolo Mancini, Comparing media systems: three models of media and politics, Cambridge University Press, 2004 , p. 279.

11 Toril Aalberg, Peter van Aelst and James Curran, 'Media Systems and the Political Information Environment: A Cross-National Comparison', The International Journal of Press/Politics, 15, 3, 2010, 255-271.

12 James Curran, 'Rethinking the media as a public sphere' in: Peter Golding and Graham Murdock, eds., The Political Economy of the Media. Vol. 2. Communication and the Common Good, Edward Elgar, 1997, p. 140.

13 Daniel C. Hallin, 'Neoliberalism, social movements and change in media systems in the late twentieth century' in: David Hesmondhalgh and Jason Toynbee, eds., The media and social theory, Routledge, 2008, p. 55. 
It is a task and challenge for lawmakers to find the right balance in media regulation, which will secure the existence of the dual media system consisting of private and public broadcasting —minimum regulation enabling free market-driven development of a commercial sector and supportive legal framework securing the fulfilment of the remit of a public service broadcasting.

For media development, market size determines the available resources. ${ }^{14,15}$ If the market is large enough for profitable businesses and the resources are available, the general media tasks (variety, pluralism etc.) can be fulfilled. In smaller countries, there are fewer available resources and there is a risk of market failure. ${ }^{16,17}$ Due to market limitations, it is unprofitable to launch a wide range of media products in smaller markets. The diversity of content offered will be lower in smaller and poorer countries than in the larger and richer markets. Estonia, with a population of about 1.3 million and a per capita GDP that is about $30 \%$ lower than the EU-28 average, ${ }^{18}$ is a small country with very limited resources, which has directly influenced the development of the media landscape. ${ }^{19}$ Media convergence and globalisation make it increasingly difficult to effectively regulate national or regional media markets. ${ }^{20,21,22,23}$

The article tackles one of the issues of this complexity—reciprocal dependency of commercial broadcasters' financial interest and changes to the broadcasting legislation to meet these concerns while adopting relevant changes of the European directives. The following analysis of the evolution of Estonian broadcasting legislation shows important connections between private broadcasters' interests and the changes in the legal environment. The article argues that Estonian legal regulation of the broadcasting sector is dominated by a liberal free market approach ${ }^{24}$ and has been biased towards the protection of the economic interests of private media enterprises.

\section{The New Birth of Broadcasting}

In Estonia, regular radio broadcasts began in 1926 and regular television transmissions in 1955. Radio broadcasts were started by o/ü Raadio Ringhääling, a private company that was subjected to state control in 1930, and thereafter, was nationalised and renamed Riigi Ringhääling (State Broadcasting) in 1934. ${ }^{25}$ In 1940, State Broadcasting was abolished and the occupying German military forces took control of broadcasting. During the Soviet occupation after World War II, all broadcasting was controlled by the Communist Party. Until the early 1990s, the main TV channels broadcasting in Estonian territory were Estonian Television (ETV) and three channels from Russia: Ostankino TV,

14 Manuel Puppis, 'Media regulation in small states' in: International Communication Gazette 71, 7, 2009, 7-17.

15 Gregory Ferrel Lowe and Christian S. Nissen, eds., Small among Giants. Television Broadcasting in Smaller Countries, Nordicom, University of Gothenburg, 2011.

16 Gillan Doyle, Media Ownership: The economics and politics of convergence and concentration in UK and European media, Sage, 2002.

17 Andres Jõesaar, 'Different ways, same outcome? Liberal communication policy and development of public broadcasting,'. In TRAMES,

15(65/60), 1, 2011, 74-101.

18 GDP per capita, consumption per capita and price level indices. Eurostat Statistics Explained. Eurostat. 2016. http://ec.europa.eu/eurostat/ statistics-explained/index.php/GDP_per_capita,_consumption_per_capita_and_price_level_indices

19 Andres Jõesaar, 'Formation of Estonian Broadcasting Landscape 1994-2007: Experience of the Transition State', Central European Journal of Communication, 2, 1(2), 2009, 43-62.

20 Indrek Ibrus, 'The replacement of media policies with (media) entrepreneurship policies: A view from Europe's periphery', International Journal of Digital Television, 6, 3, 2015, 311-318.

21 Harvey Jassem, 'Convergence Kills Media Policy: Can Freedom of Expression Be Next?', in: Susan J. Drucker and Gary Gumpert, eds., Regulating Convergence, Peter Lang, 2010, 21-36.

22 Michael Latzer, 'Convergence, Co-evolution and Complexity in European Communications Policy', in: Karen Donders, Caroline Pauwels and Jan Loisen, eds., The Palgrave Handbook of European Media Policy, Palgrave, 2014.

23 Alison Harcourt, The European Union and the regulation of media markets, Manchester University Press, 2005.

24 Andres Jõesaar, 'Different ways, same outcome? Liberal communication policy and development of public broadcasting' in: TRAMES, 15(65/60), 1, 2011,74-101.

25 Vello Lään, Eesti Raadio. Esimesed 70 [Estonian Radio. First 70], Eesti Raadio, 1996. 
Russia TV (both re-transmitted from Moscow) and Leningrad TV. The re-transmission of all Russian television channels was terminated between 1993 and $1994 .{ }^{26}$ The frequencies and networks they had occupied were licensed to newly-created private Estonian broadcasters, and new frequencies were opened for the expanding public broadcaster and emerging private broadcasters.

After regaining its independence, Estonia totally reformed its media. What had formerly been the State Radio and Television Committee was reorganised into two independent public service institutions: Estonian Radio and Estonian Television. It was decided that Estonian Radio and Estonian Television would have two main sources of revenuefunding from the state budget and the sale of advertising time. The latter soon caused a heated conflict with the private broadcasters.

During the licencing process for the newly created private broadcasting companies in the early 1990s, media policymakers were particularly concerned about protecting the emerging markets from foreign capital, the enrichment of Estonian culture and the development of the media space. Therefore, between 1992 and 1994, the licence's terms included a requirement that foreign ownership could not exceed 10\%. After 1994, Estonian capital in the broadcasting organisation at least $50 \%$ of the votes had to be of Estonian origin, as did at least $35 \%$ of the daily output of a radio programming.

The first temporary licences for new private broadcasters were issued in 1992. Between May 1992 and January 1994 a total of 47 licences were issued by the Ministry of Culture: 15 for television and 32 for radio. The first two licences were granted to new private radio companies (AS Trio and AS Rumor), and the third licence was for a municipal radio station in Viljandi County. Estonian Television and Estonian Radio received licences numbered $\mathrm{KU}-4$ and KU-5. This order is indicative of the political atmosphere and priorities. Officially, the owners of the first two Estonian private television licences were AS Alo TV (Alo TV) in Tartu and Eesti Kristlik Televisioon (Estonian Christian TV). The former started as a local channel; the latter never operated as a broadcaster and limited its activities to the production and distribution of religious programmes. Of the first 15 TV licence owners, only five actually started broadcasting television programmes. The rest limited their activities to producing TV films or series or did not start operating at all.

In September 1992, AS Taska (Kanal 2, licence KU-17), AS Orsent Ltd. (Orsent, licence KU-19) and AS Reklaamitelevisioon (RTV, licence KU-20) received licences. AS Eesti Video (EVTV, licence KU-27) received a licence in May 1993. Together with Alo TV, these companies formed the foundation of private broadcasting in Estonia. EVTV, RTV and Kanal 2 became the main players on the Estonian television landscape.

RTV started by broadcasting on ETV's frequencies on Saturday and Sunday mornings. The business model for RTV was copied from Finland, where commercial broadcaster Mainos TV Oy had the exclusive rights for the sale of advertising time on the public service broadcaster Yleisradio. A similar agreement was made between ETV and RTV, and the latter received a 15\% commission on the sales of advertising time. Mainos TV Oy and ETV were two of the ten companies that founded Reklaamitelevisioon AS, and they both had $10 \%$ of the shares. Ten percent was the maximum percent of shares that could be owned by a foreign investor at the time.

AS Eesti Video was co-owned equally by Estonian citizens Viktor Siilats and Andres Küng, who was an Estonian citizen living in Stockholm. IImar Taska, the sole owner of AS Taska, was residing in the United States. Alo TV's founder was Estonian citizen Tõnis Mets. While RTV and EVTV produced a broad range of original programming, Kanal 2 started out as a film channel and made minimum investments in original programming. Alo TV was established mainly, but not exclusively, as a music channel, and it still maintains its role as a promoter of Estonian music today. Live performances of hundreds of Estonian musicians have been recorded and a valuable archive of Estonian music has been created. 
Orsent was, and continues to be, owned by Aleksandr Titov. Orsent is the only television company whose ownership has not changed. All of Orsent's programming was in Russian and targeted a Russian-speaking audience, but its weekly broadcasts totalled only around six hours. In its licence application to the Licensing Commission of the Ministry of the Culture, Orsent described its goal as contributing to the integration of the local Russian minority into Estonian and global culture. ${ }^{27}$ In its submitted application, Orsent declared that it intended to produce programmes that would be broadcast only three hours a week after RTV's programme in the Tallinn area. The same frequency was also used by AS Reklaamitelevisioon to broadcast its RTV programme. Although the channel was on the air for only a few hours each week and the programmes were aired at inconvenient times for the viewers, Orsent must be recognised as the first free-to-air Estonian TV station broadcasting to the Russian-speaking audience. Twentythree years passed before the launch of the public service channel ETV+, which also targeted the Russian-speaking audience. Today, Orsent has its own channel and broadcasts considerably more programme hours. Orsent's audience figures were, and still are, very small. ${ }^{28}$ The station has never become an important platform or voice for the Russian-speaking audience.

Of the early start-ups, only Kanal 2, Alo TV and Orsent are still operating under the same names. Of the early private radios, only Kuma Raadio, Ring FM, Nõmme Raadio and the stations in the Trio group are still on the air.

\section{Broadcasting Act}

It took two years to draft the Broadcasting Act, which established Estonia's comprehensive media legislation. The Broadcasting Act, ${ }^{29}$ drafted with the aid of experts from the Council of Europe and the European Broadcasting Union, reflected the expectations of the politicians and Estonian broadcasting experts in the 1990s. The drafting of the Broadcasting Act was strongly influenced by the European Convention on Transfrontier Television ${ }^{30}$ and the Television without Frontiers Directive (TWFD). ${ }^{31}$ The primary objective of the 1994 Broadcasting Act was to establish a dual media system, with public-service broadcasting (PSB) coexisting with commercial broadcasting. To balance the revenue streams of these two sectors, the sale of advertising time on Estonian television and Estonian radio was limited to five minutes per hour. This was the first legal step to limit ETV's activities on the commercial market in order to create a favourable climate for the development of private channels. Based on the TWFD, the maximum time limit for commercials on private channels was set at 12 minutes in any section of a programme, and up to a total of $15 \%$ of the programme's daily broadcast.

The enactment of the new legislation was a big step forward in establishing the broadcasting landscape in Estonia. The law sought to create a new order suitable for a young democratic state and to secure freedom of speech, as well as to promote the development of a free market economy. In practice, this meant the minimal regulation of the press, which has resulted in Estonia being in the top ten in the Reporters without Borders (RSF) World Press Freedom Index for several years. ${ }^{32}$

Since 1992, licences for private broadcasters have been issued through public tenders. The first version of the Broadcasting Act from 1994 defined broadcasting and programmes and stipulated several requirements related thereto.

27 Orsent 1992 - Application letter. Ministry of Culture 09_03_1992.

28 Television Audience Surveys. Kantar Emor.

29 Ringhäälinguseadus [Estonian Broadcasting Act]. RT I 1994, 42, 680. Riigikogu, 1994. https://www.riigiteataja.ee/ert/act.jsp?id=28671

30 Council of Europe, European Convention on Transfrontier Television, 1989. https://rm.coe.int/CoERMPublicCommonSearchServices/ DisplayDCTMContent?documentld=090000168007b0d8.

31 Council Directive 89/552/EEC of 3 October 1989 on the coordination of certain provisions laid down by Law, Regulation or Administrative Action in Member States concerning the pursuit of television broadcasting activities, 1989. http://eur-lex.europa.eu/legal-content/EN/TXT/ HTML/?uri=CELEX:31989L0552\&:from=EN

32 Reporters Without Borders. The World Press Freedom Index, 2016. https://rsf.org/en/world-press-freedom-index. 
Based on the law and the terms of the broadcasting licence, a broadcasting station has the right to freely decide the contents of its broadcasts and programmes; however, a special requirement applied to news programmes. At least $5 \%$ of the daily programme time had to consist of news programmes except on Sundays and national holidays. This was the only specific content-related obligation required of the broadcasters.

The stipulation of these obligations reflects the liberal media policy of the legislators at the time. The issuance of broadcasting licences was also liberal; all the unoccupied technical frequencies were distributed. The hope was that the market would regulate itself. The economic conflict that the small size of the broadcasting market would cause had yet to be perceived when the Broadcasting Act was drafted and enacted.

After the Broadcasting Act was passed in the spring of 1994, all previously issued temporary licences became invalid, and 30 new five-year broadcast licences were issued amidst tight competition-11 for television and 29 for radio. Estonian Radio and Estonian Television no longer needed to apply for the broadcasting licences, as they now functioned according to the rules set out in the Broadcasting Act.

Three competitors_EVTV, Kanal 2 and RTV—applied for the transmission networks left free after the termination of Moscow's two television channels. Kanal 2 applied for Leningrad TV's frequencies, which had less terrestrial coverage than the channel he was already operating. Competitors EVTV and RTV both applied for a second network with large terrestrial coverage. The commission decided to make a compromise, and EVTV received a licence to broadcast on Mondays, Wednesdays, Fridays and Sunday evenings, and RTV on Tuesdays, Thursdays, Saturdays evenings and Sundays mornings. At the same time, the ETV-RTV agreement was terminated, and ETV started selling its own advertising time.

As mentioned above, one aim of the broadcasting legislation was to provide protection from foreign capital. Despite the legislators' intention to favour local capital, the executive powers continued to issue broadcasting licences to the representatives of foreign capital. AS Eesti Video, with $50 \%$ of its stock owned by Andres Küng, an Estonian citizen residing in Stockholm, and AS Taska, whose sole owner, IImar Taska, was then residing in the United States, were the first to receive new broadcasting licences for their channels. Although based on the law, local entrepreneurs should have received preferential treatment. The third national player, the commercial broadcaster $A S$ Reklaamitelevisioon, with $90 \%$ of its shares owned by Estonian companies, received a broadcasting licence with the least favourable terms. ${ }^{33}$

In the early 1990s, all private television stations were experiencing economic difficulties, and they had to look for additional investors in order to cover their losses. The first major (and still existing) investment was made by the Swedish media group Modern Times Group AB (MTG) when it acquired the majority share in the commercial EVTV channel. To avoid conflicts with the Broadcasting Act, the owners of EVTV drafted a contract which stated that Estonian citizens had the formal majority of the vote (which was required by the law) despite their smaller number of shares. The same solution was used in 1995 and 1996 when EVTV and RTV merged to form the new TV3 station, which was actually owned by MTG. In order to comply with the law, the Norwegian media company Schibsted ASA used the same scheme when it acquired the Kanal 2 shares in $1995 .{ }^{34}$ In the case of Kanal 2, there was also the problem of potential media concentration. The owner of Kanal 2, the Eesti Meedia AS, also owned, and still owns, the largest daily newspaper, several county newspapers and has acquired a chain of radio stations. In practice, this was a clear violation of the anti-media concentration article in the Broadcasting Act, but due to a lack of will and the (claimed) inadequate wording of the law, the executive power, which should have been responsible for supervising the broadcasting licences, never addressed the problem. ${ }^{35}$

33 Andres Jõesaar, 'Avalik-õigusliku ringhäälingu legitimatsioon: Eesti kogemus rahvusvahelises kontekstis. [The legitimation of the public broadcasting. Estonian experience in the international context.]', Tartu Ülikool, 2005.

34 Orsent 1992 - Application letter. Ministry of Culture 09_03_1992.

35 Television across Europe: regulation, policy and independence. Volume 1. Monitoring Reports. Open Society Institute, 2005. https://www. opensocietyfoundations.org/sites/default/files/volone_20051011_0.pdf 
The year 1995 also saw the continued expansion of private broadcasters. Nineteen new radio licences and one TV licence were issued. Between 1996 and 1998, the number of broadcasting licences issued decreased due to a shortage of free frequencies. A total of 14 licences were issued during those years: three for television and 11 for radio. Of the TV licences, one was given to TV3. The second new licence was given to Eesti Sõltumatu Televisioon AS, which started broadcasting as TV1 in the autumn of 1997. TV1 was promoted as a station with ambitious plans to become the market leader, but it ended up in bankruptcy only three years later, partly because of their wrong estimation of the local market.

Between 1999 and 2002, most of the valid five-year broadcast licences were renewed. No new terrestrial TV channels were granted. There were 12 cable TV licences issued in 2001, of which five belonged to the operator AS STV and targeted the Russian-speaking audience.

There were 24 newcomers in the field of radio, most of which either replaced defunct stations or resulted from a change in or consolidation of owners. Local studios were shut down, and instead of original local programming, the stations aired centrally produced programmes. The root cause of this was affordability; in smaller regions, there was insufficient advertising money or human resources to produce and air many local programmes. By this time, two major commercial radio companies_-AS Trio and Taevaraadio AS, both operating five to six radio stations-achieved the highest market shares and established themselves as the main competitors of the public Estonian Radio, which had four channels at that time.

\section{Major Changes Before Accession to the European Union}

To bring the law of the Estonian Republic into conformity with the European Union (EU) before accession to it, major changes were enacted in $1999^{36}$ and $2000 .{ }^{37}$ The obligations instituted for the broadcasting organisations were consistent with EU requirements: $10 \%$ of broadcasting time had to be reserved for independent European producers, and the majority of the broadcasting time had to be reserved for European programming. It is important to point out that the Estonian legislators set an additional obligation: $10 \%$ of the programming had to be acquired from independent producers (dealing with Estonian current events and cultural heritage), and of this, $50 \%$ had to be broadcast during prime time. This obligation was eliminated from the legislation in 2010 when the Audiovisual Media Service Directive (AVMSD) ${ }^{38}$ was implemented.

Despite the law's noble objectives, the programme selection offered to viewers was not diversified, and the private channels did not broadcast more programming about current affairs in Estonia or Estonian cultural heritage ${ }^{39}$. Of course, this would perhaps not be true if the entertainment shows and drama series produced in Estonia could be considered a reflection of current affairs and are, or could become, part of Estonia's cultural heritage.

36 Ringhäälinguseaduse muutmise seadus. [Amendment of the Broadcasting Act]. RT I 1999, 59, 613, Riigikogu, 1999. https://www.riigiteataja. ee/ert/act.jsp?id=77606

37 Ringhäälinguseaduse muutmise seadus. [Amendment of the Broadcasting Act]. RTI 2000, 35, 220, Riigikogu, 2000. https://www.riigiteataja. ee/ert/act.jsp?id=71964\& replstring=33

38 Directive 2010/13/EU of the European Parliament and of the Council of 10 March 2010 on the coordination of certain provisions laid down by law, regulation or administrative action in Member States concerning the provision of audiovisual media services (Audiovisual Media Services Directive) http://eur-lex.europa.eu/LexUriServ/LexUriServ.do?uri=OJ:L:2010:095:0001:0024:en:PDF

39 Heikko Gross, 'Tele- ja raadiokanalite programmianalüüs [Analys of Television and Radio Programmes]'. In: Indrek Ude and Peeter Vihalemm, eds, Eesti Akadeemilise Ajakirjanduse Seltsi aastaraamat 2010/2011. Tartu: Eesti Akadeemiline Ajakirjanduse Selts. 2011. 
Another EU requirement was the elimination of limitations on the broadcasters' proprietary relationships. In 2000, the Parliament of Estonia adopted the Amendment to the Broadcasting Act,$^{40}$ which brought the latter into conformity with EU requirements (mainly those arising from the Television without Frontiers Directive). The Estonia-centric limitation on broadcasting licence ownership was revoked. From the aspect of the free movement of capital, this was a case of liberalising a protectionist market, at least for a while.

An amendment to the Broadcasting Act that was adopted in 2001 and which prohibited the broadcasting of commercial and sponsorship announcements on Estonian Television as of 1 July 2002, and on Estonian Radio as of 1 Jan $2005,{ }^{41}$ had a major impact on commercial broadcasters' revenues. A subsequent amendment to the Act introduced a licence fee for commercial broadcasters, limited the number of national broadcasting licences to two and closed the market to newcomers. Policymakers ignored the fact that this protectionist act contradicted European ideals.

\section{The Golden Years}

Both changes—the liberalisation of the proprietary rights mentioned earlier and the closure of the market—directly served the interest of the international media companies that were already in the market. Now, they officially became the sole owners of the private and monopolised broadcasting stations. Kanal 2 was $100 \%$ owned by Norwegian Schibsted ASA, and TV 3 was $100 \%$ owned by Swedish MTG. The law was brought into conformity with the existing situation. Secondly, the closure of the market ensured them an advantageous economic environment. The results of the changes are evident in the changes in the companies' profitability between 2002 and 2007.42,43

Between 2004 and 2008, only a few new TV licences were issued, and all of them were local licences. OÜ Lites $L T$ started the LiTeS programme in East-Virumaa in 2004; the non-profit AB Video started the TV-N programme on the Harjumaa and Tallinn cable network in late 2006 (it is now available throughout Estonia). And in 2008, the SA Lastekaitsefond's programme LNTV was launched, which broadcast cartoons during the few years it was in operation.

For more efficient operations, Estonian Radio and Estonian Television were merged into a new legal entity, Estonian Public Broadcasting (ERR), in 2007, and the corresponding law was enacted. ${ }^{44}$ In 2008, ERR launched its second television channel, ETV 2, and in 2015, its third television channel, ETV+. As previously mentioned, ETV+ is targeted at Russian-speaking audiences.

The profitable times for commercial television companies lasted until 2008. Starting in the mid-2000s, new media developments and the rapidly increasing numbers of new foreign channels transmitting through cable, as well as satellite TV and emerging IPTV platforms, complicated the positions of the Estonian commercial broadcasters.

Broadcasters faced a decrease in audiences and losses in revenue. The 2008 economic recession reduced the value of the Estonian advertising market by more than $40 \% .{ }^{45}$ In addition, the switch from terrestrial analogue transmission to a digital platform in 2010 increased competition even more.

40 Ringhäälinguseaduse muutmise seadus. [Amendment of the Broadcasting Act]. RT I 2002, 3, 5, Riigikogu, 200. https://www.riigiteataja.ee/ akt/162838

41 Ringhäälinguseaduse muutmise seadus. [Amendment of the Broadcasting Act]. Riigikogu, RT I 2002, 3, 5, Riigikogu, 2002. https://www. riigiteataja.ee/ert/act.jsp?id=162838

42 e-Business Register. Centre of Registers and Information Systems, 2016. https://ariregister.rik.ee/

43 Andres Jõesaar, 'The Undercurrents of Estonian Broadcasting Regulation. 1992-2014', Baltic Screen Media Review, 2015.

44 Estonian Public Broadcasting Act, RT I 2007, 10, 46, Riigikogu, 2007. https://www.riigiteataja.ee/en/eli/509012014002/consolide

45 Baltic Media Advertising Market 2009. TNS Emor, 2009. http://www.emor.ee/public/documents/uudised/BalticMediaMarket2009.pdf 
To support the digital transition and ease the difficult financial situation of the private broadcasters, the Amendment of the Broadcasting Law in 2008 annulled the broadcasting licence fees as of 1 January $2009 .{ }^{46}$ The move by the legislators to support the commercial broadcasters took place in 2012 when the Estonian Parliament adopted an amendment to the Electronic Communication Act, allowing '[b]roadcasters offering free-to-air television services to have the right to ask cable operators to pay a reasonable fee for retransmitting their television programs. ${ }^{47}$ This provided an opportunity for private broadcasters to earn additional revenue.

It should be recognised that, despite the favourable legal environment and oligopoly structure in the market from 2001 to 2007, the unfavourable circumstances in recent years have caused considerable financial losses. As a result, during their entire existence, the two main commercial broadcasters in Estonia have had a cumulative negative financial result. $x$. $O n$ the programming side, commercialisation is still a trend, but recently, acquisition-driven entertainment has been replaced by local entertainment content. ${ }^{48,49,50}$ Implementation of the Audiovisual Service Directive ${ }^{51}$ in 2010 liberalised some advertising conditions, but it didn't bring any considerable relief for commercial broadcasters.

\section{No Digital Salvation}

The digital switchover significantly increased the theoretical number of possible television channels that could be transmitted. Before the switchover, there were only four national television channels; after the switchover, the maximum technical capacity of channels on three multiplexes increased to 30 . This opportunity was moderately used by the local players. In 2010, Kanal 2 launched two sister channels, Kanal 11 and Kanal 12; TV3 added one channel, TV6. In 2011, the municipal Tallinna Televisioon (TTV) was launched, and soon it also occupied one slot on the nationwide multiplex. In 2013, an Estonian-owned pan-Baltic package, which includes the cartoon channels Kidzone, Kidzone TV (and since 2016, Kidzone Plus) and movie channels Filmzone and Filmzone Plus, was launched. Music channels Alo TV and Seitse (and since 2016, My Hits TV as a new channel in the Kanal 2 family) are also among the digital platform offerings. However, the majority of the channels available on the terrestrial digital platform are foreign pay-TV channels, some of which have Estonian subtitles (for example, Fox, Fox Life, Sony Turbo, Sony Entertainment, National Geographic Channel and others).

As of 1 Aug 2017, there were 15 valid TV licences in Estonia ${ }^{52}$ (Technical Regulatory Authority 2017). Of these 15, only one-Tallinna Televisioon-is a free-to-air television channel. The three public broadcasting (ERR) TV channelsETV, ETV 2 and ETV+-increase the number of free-to-air channels to four. Of these channels, TTV has a marginal market share and the ERR channels have around $18 \%$ of the television viewing market. The other 13 are national pay-tv channels, and one is a regional pay-tv channel. Of these, Kanal 2, Kanal 11, Kanal 12, MyHits and TV3, with its sister channel TV6, have more than $30 \%$ of the television viewing market. In total, this comprises only $5 \%$ of the

46 Ringhäälinguseaduse muutmise seadus. [Amendment of the Broadcasting Act]. RT I 2008, 28, 184, Riigikogu, 2008. https://www.riigiteataja.ee/ akt/12984725

47 Elektroonilise side seaduse $\S 90$ täiendamise seadus. [Amendment of the Electronic Communication Act § 90], RT I, 07.11.2012, 1, Riigikogu,

2012. https://www.riigiteataja.ee/akt/107112012001

48 Ulrike Rohn, 'Lacuna or Universal? Introducing a new model for understanding cross-cultural audience demand', Media, Culture \& Society, 334 , 2011, 631-641.

49 Indrek Treufeldt, 'Kvaliteet televisioonis [Quality in television]', in: Indrek Ude and Peeter Vihalemm, eds., Eesti Akadeemilise Ajakirjanduse Seltsi aastaraamat, 2009/2010, Tartu Ülikooli Kirjastus, 2011, 114-119.

50 Hagi Shein, 'Rahvusringhäälingu kuvandimaastik [Public Broadcaster's representational landscape]' in: Indrek Ude and Peeter Vihalemm, eds., Eesti Akadeemilise Ajakirjanduse Seltsi Aastaraamat 2009/2010, Tartu Ülikooli Kirjastus, 2011, 92-104.

51 Media Services Act RT I, 06.01.2011, 1, Riigikogu, 2011. https://www.riigiteataja.ee/en/eli/ee/509072014004/consolide

52 Meediateenuste load_nimekiri [List of media service licences]. The Estonian Technical Regulatory Authority, 2017. http://www.tja.ee/ meediateenuste-load-2/ 
361 channels available in the Estonian television market. ${ }^{53}$ As of 1 Aug 2017, there were 31 valid radio licences in Estonia. ${ }^{54}$ Although the number of licences seems high for a market as small as Estonia, the commercial competition at the national level since the late 1990s has been comprised of two main groups, Trio LSL AS and Taevaraadio AS. These companies hold 12 radio licences (six each) and for a long time had more than $50 \%$ of the audience share. ${ }^{55}$ The share of Estonian Public Broadcasting, which is the market leader operating five radio programmes, is declining, but its share still comprises almost one-third of the market. These three media groups together have more than $80 \%$ of the market. The third commercial player, Mediainvest Holding AS (former MTG company, now owned by Providence Equity Partners), operated two commercial stations until 2015 and added a third station in 2016.

\section{Back to the Beginning}

From the early 1990s to mid-2000s, Estonian media enterprises developed primarily with the help of Western investments; generally, Nordic media companies became the owners of these enterprises. The Norwegian Schibsted ASA purchased Postimees the largest-circulation national newspaper, several county newspapers, the Kanal 2 TV station, a printing house and, subsequently, also shares in the Trio radio group (which altogether are under Eesti Meedia AS). The Finnish Mainos TV invested in AS Reklaamitelevisioon, which later merged with EVTV to form TV 3, part of the Swedish Modern Time Group. MTG also founded three radio stations. The main goal of the foreign companies that invested in the Estonian media sector was to profit from a newly opened market. As we now see, interest in an active presence in the market has diminished and many of the foreign investors have pulled out of the market. In 2015, Schibsted sold all of its Baltic businesses, and Eesti Meedia AS is now solely owned by Estonian businessman Margus Linnamäe; another Estonian entrepreneur, Hans H. Luik, bought all the shares of the Ekspress Grupp AS back from its Swedish owners. In 2017, MTG sold all its Baltic media businesses to Providence Equity Partners, a US investment company.

One could call this trend business localisation, which tries to provide a balance for growing media globalisation. Globalisation has introduced new business models with the pan-European and global media enterprises that offer universal products and services, increasing their shares in national markets. It remains to be seen if local owners with local competencies can stand up to these companies and still earn the profits needed for national media sustainability. As shown in this analysis so far, the legal framework has been supportive of private businesses, and there is no reason to believe that there will be any negative changes for them in the Estonian media policy. Quite the opposite: triggered by the revision of the AVSMD directive, an even more liberal approach to media regulation most likely will be put in place soon. Still, media policy development cannot be interpreted as being one sided. It remains to be seen how further developments in media policy drafting will deal with the two main conflicting issues described by Ibrus: ${ }^{56}$

- the ideological lock-ins that cause Estonia's cultural policy goals to be sacrificed for other goals, such as broad market liberalisation and normative globalisation in the digital services sector;

- how complex international developments are challenging a small peripheral country such as Estonia and how much freedom it has (if any) to design its national media system and ensure its survival.

53 MAVISE Database on TV and on-demand audiovisual services and companies in Europe. European Audiovisual Observatory, 2016. http:// mavise.obs.coe.int/

54 Meediateenuste load_nimekiri [List of media service licences]. The Estonian Technical Regulatory Authority, 2017. http://www.tja.ee/ meediateenuste-load-2/

55 Raadioauditooriumi ülevaated [Radio audience reports]. Kantar Emor, 2016. http://www.emor.ee/index.php?op=search\&query= raadioauditoorium

56 Indrek Ibrus, 'The EU digital single market as a mission impossible: Audio-visual policy conflicts for Estonia', International Journal of Digital Television, 7 (1), 2016, 16-17. 
As shown in this research, Estonian media policy drafters have extensively taken into account the (financial) interests of major stakeholders in recent decades and have adopted media legislation accordingly. It remains to be seen how recent changes in media ownership will influence additional upcoming changes in national media legislation. One thing is certain: changes will come; if they are not driven by local interests, then surely by the implementation of a new version of the AVSMD.

\section{Biography}

Dr. Andres Jõesaar is Vice-Rector for Creative Activities and Cooperation at Tallinn University. He also acts as a head of media and communication study area at Tallinn University Baltic Film, Media, Arts and Communication School. In parallel he is also heading the media research department of Estonian Public Broadcasting and is a member of The Group of European Audience Researchers (GEAR) at European Broadcasting Union. Jõesaar has a long experience in the media and telecommunications industries, especially on the management and content side. He was one of the founding members of the private commercial television channel Reklaamitelevisioon and the general director of the commercial television channel TV3 Estonia owned by Swedish media corporation Modern Times Group. From 2000-2011 he was the director for the on-line and mobile content services in the Estonian branch of the international telecommunication company Tele2. Between 2000-2012 Jõesaar has been the chairman of the Council of the Estonian Public Broadcasting. He has been a member of the Council of Europe's expert groups and active in other various national (including OSCE) and international expert and working groups. Main research areas are media policy and economy and new media/media convergence. Jõesaar has a $\mathrm{PhD}$ on media and communication from the University of Tartu. 